\author{
(online) $=$ ISSN $2285-3642$ \\ ISSN-L = $2285-3642$ \\ Journal of Economic Development, Environment and People \\ Volume 2, Issue 3, 2013 \\ URL: http://jedep.spiruharet.ro \\ e-mail: office jedep@spiruharet.ro
}

\title{
Industrial Pollution Regulation in the EU and in Macedonia, Serbia and Croatia
}

\author{
Prof. Aleksandar Chavleski, PhD \\ FON University, Skopje, Macedonia
}

\begin{abstract}
.
Industrial pollution control has substantial impact in the protection of the environment. In the European Union, there's vast legislation in this field consisting mainly of the Directive on industrial emissions of 2010 aimed at consolidating the so far existing legislation in this field. The new Directive on industrial emissions aims to establish an integrated prevention and control of the pollution arising from industrial activities and it lays down rules designed to prevent or, where that is not practicable, to reduce emissions into air, water and land and to prevent the generation of waste, in order to achieve a high level of protection of the environment taken as a whole. Macedonia, Serbia and Croatia have made significant progress in this field in the recent years as part of their obligations under the Stabilization and Association Process. The purpose of this particular article is to evaluate the degree of alignment and implementation of the environmental legislation in this particular area with the legislation of EU as well its practical application, and to identify the existing deficiencies and necessary steps for action
\end{abstract}

Keywords: industrial installations, emission limit values, integrated control and prevention

JEL Codes: Q56, Q58

\section{Introduction}

Industrial installations are largely responsible for the most of the total amount of industrial in the air, water and soil, and generate significant quantities of waste. Although their activities are important in order to provide economic well - being, an account must be taken on the effects on the environment and people's health. That's why since the 1970s in EEC and later the European Union the industrial emissions were subject to regulation by several directives, which were finally replaced by single Directive on industrial emissions in 2010. The new Directive also sets new stricter values for certain polluting substances, a time frame for their reduction, new revision procedures for the integrated permits, better procedures for public participation, access to justice etc. The new Directive puts new obligations for the Member States and dynamics for their implementation. The alignment and effective implementation of the legislation in the area of Industrial pollution control and risk management (as a important component of the overall Environmental Policy of the European Union) in Macedonia, Serbia and Croatia is an ongoing process. This article will give comparison between the regulation of industrial pollution control in EU and in Macedonia, Serbia and Croatia, and will identify potential disparities in the process of alignment of the legislation in these countries. 


\author{
(online) = ISSN $2285-3642$ \\ ISSN-L = $2285-3642$ \\ Journal of Economic Development, Environment and People \\ Volume 2, Issue 3, 2013 \\ URL: $\underline{\text { http://jedep.spiruharet.ro }}$ \\ e-mail: office jedep@spiruharet.ro
}

\title{
2. Industrial pollution regulation in the European Union
}

In the 1970s the concerns over the acid deposition in the EEC begun to rise. Since then, vast array of secondary legislation has been passed in order to tackle this problem. The Large Combustion Plant Directive 88/609/EEC targeted the reduction of sulphur and nitrogen oxides from the plants more powerful than 50 MW burning fossil fuel. In 2001 this Directive was revised and promoted combined generation of heat and power, putting an emission limit values for using biomass as fuel ${ }^{1}$. Also, the other relevant legislation in the field include Solvent Emissions Directive 1999/13/EC, the 1996 IPPC Directive, then Landfill Directive 1999/31/EC, Waste Incineration Directive 2000/76/EC, as well as the three existing directives on Titanium dioxide on (i) disposal (78/176/EEC), (ii) monitoring and surveillance $(82 / 883 / E E C)$ and (iii) programs for the reduction of pollution $(92 / 112 / E E C)$.

In 2005 European Commission started a process of revision of the existing legislation on industrial emissions with an aim to promote clearer environmental benefits, to eliminate the existing ambiguities and to encourage technological innovation. In December 2007 a proposal of the new Directive was launched by the Commission and in June 2010 a political agreement between the Member States was reached.

In November 2010, the new Directive on industrial emissions ${ }^{2}$ was enacted consolidating most of the existing legislation in the field. The new Directive is directed at prevention and control of the pollution from the industrial activities through a system of permits for operation of the installations or combustion plants, waste incineration plants or waste co-incineration plants. The Member States are obliged that all industrial installations are operated in line with several general principles like: 1) all appropriate measures for prevention of pollution are taken; 2 ) application of BAT; 3 ) there will be no significant pollution from the operation of the plant; 4) generation of waste will be prevented in accordance with the Directive 2008/98/EC; 5) efficient use of energy and 6) all necessary measures to prevent accidents are taken and their eventual consequences are limited, etc. ${ }^{3}$ Also, where an environmental quality standard requires stricter conditions than those achievable by the use of the Best available techniques, additional measures shall be included in the permit.

Furthermore, the Directive sets these minimum conditions for granting the permit by the Member States' competent authority: emission limit values for polluting substances listed in Annex II of the Directive, and for other polluting substances, which are likely to be emitted from the installation concerned in significant quantities, that appropriate arrangements ensuring protection of the soil and groundwater and measures concerning the monitoring and management of waste generated by the installation are

\footnotetext{
${ }^{1}$ Tiwary, A., Colls, J., Air Pollution: Measurement, modeling and mitigation, Abingdon, Routledge, 2010 , p. 467.

${ }^{2}$ Directive 2010/50/EU, Official Journal of EU, L 334/50, 17.12.2010.

${ }^{3}$ Art.11.
} 


\author{
(online) $=$ ISSN $2285-3642$ \\ ISSN-L = 2285-3642 \\ Journal of Economic Development, Environment and People \\ Volume 2, Issue 3, 2013 \\ URL: http://jedep.spiruharet.ro \\ e-mail: office jedep@spiruharet.ro
}

taken; suitable emission monitoring requirements are set; the competent authority is supplied regularly, and at least annually, with: information on the basis of results of previously mentioned emission monitoring and other required data that "enables the competent authority to verify compliance with the permit conditions ...", measures relating to conditions other than normal operating conditions such as start-up and shut-down operations, leaks, malfunctions, momentary stoppages and definitive cessation of operations, provisions on the minimisation of long-distance or trans-boundary pollution, conditions for assessing compliance with the emission limit values or a reference to the applicable requirements specified elsewhere etc.

Also, Member States' competent authorities can set stricter conditions for the permit than the standards achievable through the use of BAT described in the BAT conclusions. All operators are obliged to inform the competent authority of any planned change in the nature or functioning, or an extension of the installation which may have consequences for the environment. In such cases, the competent authorities should update the previous permit. These changes would be deemed to be substantial if the change or extension in itself reaches the capacity thresholds set out in Annex I of the Directive. ${ }^{4}$

Once granted the permits are subject to reconsideration and updating by the competent national authority every 4 years from the date of the publication of the BAT conclusions. On this occasion, all permit conditions are reconsidered and updated if necessary, and that the installation complies with those updated requirements. The Permit conditions are always reconsidered in a event of: 1) pollution caused by a installation is of such significance that the existing emission limit values of the permit need to be revised or new such values need to be included in the permit, 2) the use of other /new techniques is necessary for the reasons of operational safety of the facility and 3 ) where it is necessary to comply with a new or revised environmental quality standard. ${ }^{5}$

For the purposes of the assessment of the environmental effects, the Member States are obliged to carry on inspections according to an enacted plan for such inspections on national, regional and local level. Those inspections should be carried out at least on every 3 years for installations posing the lowest risk and at least every year for installations posing highest risk. Also, non-routine environmental inspections may be carried out in a event of serious complaints, accidents, incidents and occurrences of non-compliance as soon as possible and, if it is possible before the granting, reconsideration or update of a permit. ${ }^{6}$

The new Directive obliges the Member States to ensure their public has early and effective possibility to participate in the decision - making process for granting the permits to industrial installations, or any substantial change to an installation. Also, the public should take part in the process of reconsidering or updating permits where the competent authority has set less strict emission limit values for certain

\footnotetext{
${ }^{4}$ Art.20.

${ }^{5}$ Art. 21

${ }^{6}$ Art. 23
} 


\author{
(online) $=$ ISSN $2285-3642$ \\ ISSN-L = 2285 - 3642 \\ Journal of Economic Development, Environment and People \\ Volume 2, Issue 3, 2013 \\ URL: http://jedep.spiruharet.ro \\ e-mail: office jedep@spiruharet.ro
}

installation and where in an event of a pollution resulting in a significant excess of the existing emission limit values the permit needs to be revised or new such values need to be included in the permit. ${ }^{7}$ Once the decision to grant the permit is taken, the public must be informed inter alia of its content, including the copy of the permit, the consultations held and the way those consultations were incorporated in the decision, the BAT reference documents and the manner of determination of permit conditions including the emission limit values, in relation to the Best available techniques and emission levels associated with the BAT. ${ }^{8}$

Also, the public must be entitled to judicial review or review by other impartial body of the issued permits. The conditions for locus standi of the applicants are: 1) to have a sufficient interest; 2) to maintain the impairment of a right, where administrative procedural law of a Member State requires this as a precondition. While determining more concretely these conditions in national law, the Member States should have in mind the "objective of giving the public concerned wide access to justice."

The Directive itself prescribes that the interest of any non-governmental organizations promoting environmental protection and meeting any requirements under national law shall be deemed sufficient for meeting the criteria of locus standi for these review procedures. In order to facilitate the access of the public to these review procedures, Member States are obliged to ensure that practical information is made available to the public for that purpose.

Moreover, the public of a neighbouring Member State of EU is entitled to have (for an appropriate period of time) access to applications for permits in Member States where installations are located if they are going to have trans-boundary effects on the environment. Any remarks by the public should be taken in account when reaching the decision on the granting of permit by the competent authorities of the Member State where the installation is located. Once the decision is made, the competent authority shall inform the neighbouring Member State(s), who is responsible to ensure that that information is made available in an appropriate manner to the public concerned in its own territory. ${ }^{10}$

Besides these general provisions, the Directive contains special provisions regarding Large Combustion Plants. Waste Incineration and Waste Co-Incineration Plants, Installations and Activities using Organic Solvents, and on Installations producing Titanium Dioxide.

For the purpose of the Directive, Large Combustion Plants are all plants who are the total rated thermal input is equal to or greater than $50 \mathrm{MW}$, irrespective of the type of fuel used. For these plants, emission limit values are set in the part 1 of Annex 5 of the Directive. All permits granted before 7 January

\footnotetext{
${ }^{7}$ Art. 24

${ }^{8}$ Art.24

${ }^{9}$ Art. 25

${ }^{10}$ Art. 26
} 


\author{
(online) = ISSN $2285-3642$ \\ ISSN-L = 2285-3642 \\ Journal of Economic Development, Environment and People \\ Volume 2, Issue 3, 2013 \\ URL: $\underline{\text { http://jedep.spiruharet.ro }}$ \\ e-mail: office jedep@spiruharet.ro
}

2013 should include conditions these values not to be exceeded, provided that such large combustion plants are put into operation before 7 January 2014.

All permits for installations which had been granted an exemption as referred to in Article 4 (4) of Directive 2001/80/EC shall include conditions emission values not to exceed the emission limit values set out in Part 2 of Annex V of the Directive (provided such installation continue to work after January 1, 2016). All other permits concerning other installations should ensure that emissions into the air from these plants also do not exceed values set out in Part 2 of Annex V.

Under the Directive, the Commission was tasked inter alia to report to the European Parliament and Council by 31 December 2013 on the possibilities to establish Union - wide emission limit values on: diesel engines; recovery boilers within installations for the production of pulp; combustion plants within refineries firing the distillation and conversion residues from the refining of crude-oil; combustion plants firing gases other than natural gas and combustion plants in chemical installations using liquid production residues as non-commercial fuel for own consumption. Commission can produce a legislative proposal to this effect. ${ }^{11}$

The Directive provides for a possibility for Large Combustion Plants that have obtained first permit before 27 November 2002, to be exempted from the compliance with the emission limit values referred to in Article 30(2) for the pollutants which are subject to the plan or, where applicable, with the rates of desulphurisation referred to in Article 31 of the Directive. This could be done by means of transitional plans for those plants, and such plans can be adopted between years 2016 and 2020. Each transitional plan shall set a ceiling defining the maximum total annual emissions for all of the plants covered by the plan on the basis of each plant's total rated thermal input on 31 December 2010, its actual annual operating hours and its fuel use. The transitional plans should contain provisions on monitoring and reporting in accordance with Article 41 (b) of the Directive, and also should enlist all the foreseen measures for the plants in order to fulfil the requirements regarding emission values that will apply from 1 July 2020. These plans should be communicated to the European Commission by 1 January 2013. The Commission has a right to raise objections to the plan within 12 months from the receipt, and, if it does, the Member State concerned should make appropriate changes. If there're no objections in the prescribed time-limit, the plan is considered accepted. ${ }^{12}$

The Directive also provides for limited lifetime derogation for certain plants provided inter alia that the operator undertakes obligation in written form not to operate the plant for more than 17500 operating hours, starting from 1 January 2016 and ending no later than 31 December 2023. ${ }^{13}$ Also, exemption is foreseen for the combustion plants that were part of a small isolated system as they may be exempted from compliance with the emission limit values set by the Directive, but they should at least maintain the

\footnotetext{
${ }^{11}$ Art.30

${ }^{12}$ Art.32

${ }^{13}$ Art.33
} 


\author{
(online) $=$ ISSN $2285-3642$ \\ ISSN-L = 2285-3642 \\ Journal of Economic Development, Environment and People \\ Volume 2, Issue 3, 2013 \\ URL: $\underline{\text { http://jedep.spiruharet.ro }}$ \\ e-mail: office jedep@spiruharet.ro
}

emission values in accordance with the requirements of Directives 2001/80/EC and 2008/1/EC. ${ }^{14}$ District heating plants can also be exempted by 31 December 2022, provided that inter alia their thermal output does not exceed $200 \mathrm{MW}$, minimum $50 \%$ of the heat production is delivered in a form of steam through a public network and the emission limit values for sulphur dioxide, nitrogen oxides and dust are maintained until 31 January 2022 in accordance to Directives 2001/80/EC and 2008/1/EC. ${ }^{15}$

The Member States are obliged to carry out monitoring of the emissions of polluting substances especially $\mathrm{f} \mathrm{SO2,} \mathrm{NOx} \mathrm{and} \mathrm{CO}$ and dust, continuously on plants whose thermal power is 100 or more MW. According to these measurements, the competent national authority verifies the compliance of these emissions with the permit conditions.

Regarding the waste incineration and co-incineration plants, they should also obtain a permit by the competent authority. The permit should contain inter alia the types and quantities of the waste that will be treated, the capacity of the plant, to set the limit values of emission in the air and the water, the requirements for the $\mathrm{pH}$, temperature and flow of waste water discharges and the maximum permissible period of any technically unavoidable stoppages, disturbances, or failures of the purification devices or the measurement devices. For the incineration of co-incineration of hazardous waste, the permits must contain additional conditions regarding the list of quantities of different hazardous waste that will be treated and the minimum and maximum flows of the hazardous waste and their maximum contents of polluting substances. These permits are subject to periodic revision and updates by the competent authority. ${ }^{16}$

The Directive sets emission limit values for waste incineration plants in Part 3 and 4 of Annex $\mathrm{VI}$, and also for plants where more than $40 \%$ of the produced heat comes from hazardous waste, only emissions set in Part 3 of Annex VI. The report of Article 72 of the Directive regarding the waste incineration plants or waste co-incineration plants with a nominal capacity of 2 tonnes or more per hour, shall contain information on the functioning and monitoring of the plant and give account of the running of the incineration or co-incineration process and the level of emissions released into the air and water in comparison with the emission limit values. That information shall be made available to the public. The Member States' competent authorities should make available to the public a list of all such plants that have such capacity.

The installations and activities using organic solvents are also subject to special regime under the Directive. Each such installation should not produce emission over the limit values in waste gases and the fugitive emission limit values, or the total emission limit values, and other requirements laid down in Parts 2 and 3 of Annex VII of the Directive; or; 2) should respect the reduction scheme set out in Part 5 of Annex

\footnotetext{
${ }^{14}$ Art.34

${ }^{15}$ Art.35

${ }^{16}$ Art. 45 


\author{
(online) $=$ ISSN $2285-3642$ \\ ISSN-L = 2285-3642 \\ Journal of Economic Development, Environment and People \\ Volume 2, Issue 3, 2013 \\ URL: $\underline{\text { http://jedep.spiruharet.ro }}$ \\ e-mail: office jedep@spiruharet.ro
}

VII provided that an equivalent emission reduction is achieved compared to the previous condition. The conditions for limit values of waste gases are set in Part 8 of Annex VII. The operator of the plant should report to the competent national authority on its request on: 1 ) emission limit values in waste gases, fugitive emission limit values and total emission limit values; or 2) on the requirements under Part 5 of Annex VII of the Directive or 3) the derogations under Art. 59 (2) and (3). Also, the Directive prescribes that in a event of a substantial change of an existing installation the part that undergoes substantial change will be treated either as a new or either as an existing installation, provided that total emissions of the whole installation do not exceed the potential emissions that would have been released if the substantially changed part have been treated as a new installation. In such cases, the competent national authorities should assess the compliance of their emissions by the plants with the requirements posed by the new Directive. ${ }^{17}$

With a purpose of promoting environmental protection, the Member States, the industry and non governmental organizations and the European Commission are obliged to exchange information on the potential substitutes of the organic solvents and techniques that have less harmful effect on air, soil, ecosystem and human health. Those consultations inter alia should take special account of potential health risks for humans and environment, as well as the economic consequences. ${ }^{18}$

The public here also should be informed for every decision of the competent national authority including the permit and its eventual updates, as well as the list of all installations obliged to be registered and granted a permit and results of the monitoring of the emissions. ${ }^{19}$

Under the special provisions regarding the installations producing titanium dioxide, Member States are obliged to prohibit on their territory the disposal in the air, sea or the ocean of: 1) solid waste, 2) liquors arising from filtration phase of the hydrolysis of the titanyl sulphate solution from installations applying the sulphate process; 3 ) waste from installations applying the chloride process containing more than $0,5 \%$ free hydrochloric acid and 4) filtration salts, sludge and liquid waste arising from the treatment of the previous processes. ${ }^{20}$ The Directive sets limit emissions for these pollutants in the water and in the air in Part 1 and 2 of the Annex VIII respectively. The monitoring of these emissions should be ensured by the Member States and competent national organs should check compliance with the limits of the emissions set by this Directive.

The Member States also are obliged to provide the Commission with the relevant information regarding the implementation of the Directive, to send reports on the on representative data on emissions and other forms of pollution, on emission limit values, on the application of Best available techniques in accordance with Articles 14 and 15, in particular on the granting of exemptions in accordance with Article

\footnotetext{
${ }^{17}$ Art.63

${ }^{18}$ Art.64

${ }^{19}$ Art.65

${ }^{20}$ Art.67
} 


\author{
(online) $=$ ISSN $2285-3642$ \\ ISSN-L = $2285-3642$ \\ Journal of Economic Development, Environment and People \\ Volume 2, Issue 3, 2013 \\ URL: $\underline{\text { http://jedep.spiruharet.ro }}$ \\ e-mail: office jedep@spiruharet.ro
}

15(4), as well as the progress on new emerging techniques in accordance with art. 27 of the Directive. ${ }^{21}$ The European Commission in the implementation of this Directive is assisted by a special committee. ${ }^{22}$

\title{
3. Regulation of industrial pollution in Macedonia
}

Similar like Croatia, Macedonia has not passed a special Law on Industrial Pollution Control, but has regulated that issue under the general Law on Environment. ${ }^{23}$ This Law has special provisions regarding the industrial pollution control and the system of integrated permits. According to the Law, all new industrial installations or changes to the existing installations can be exercised and done only after an integrated ecological permit is obtained from the competent state organ. There are two types of this permit: Type A, which is issued by the central government - the Ministry on Environment, and Type $B$ which is issued by the local authorities. ${ }^{24}$ The types of industrial activities requiring $A$ or $B$ - type integrated permit were determined in 2005 by the Government, as well as the dynamics of application for such permits. ${ }^{25}$

The request for Type A Integrated Ecological Permit is submitted to the Ministry of Environment, and from there to the local authorities and to the general public who can submit their opinions and suggestions. All suggestions and remarks must be taken into account by the Ministry and the decision on the request must state the reasons what remarks were taken into account and which aren't. ${ }^{26}$ The conditions of the $A$ Integrated ecological permit regarding the Best available technologies are set by the Scientific and technological Commission in the Ministry of Environment. On this Commission 's proposal the Ministry sets the national reference documents on the BAT, which represent instructions on the application of the BAT in the individual industrial sectors. ${ }^{27}$

Their ministries of environment will be informed of the project if it is considered that the project can produce significant impact on the environment in another country or countries, than. If the concerned states respond to the notification, then the Macedonian Ministry sends all information regarding the project and its impact on the environment as well as the timetable for submitting the information and places where that information will be available. With the competent ministry of these countries the

\footnotetext{
${ }^{21}$ Art. 72

${ }^{22}$ Art.75

${ }^{23}$ Law on the Environment, Official Gazette of the Republic of Macedonia, 53/05, 05.07.2005.

${ }^{24}$ Art.95

${ }^{25}$ Regulation on the determination of the activities of the installations subject to integrated ecological permit or a permit for harmonization with a operational plan and timetable for submitting applications for permits for harmonization with a operational plan, Official Gazette of Republicof Macedonia, 89/05, 21.10.2005.

${ }^{26}$ Art.103

${ }^{27}$ Art.104 (5), Law on the amendment of the Law on Environment, Official Gazzete of Republic of Macedonia, 24/07, 01.03.2007.
} 


\author{
(online) = ISSN $2285-3642$ \\ ISSN-L = $2285-3642$ \\ Journal of Economic Development, Environment and People \\ Volume 2, Issue 3, 2013 \\ URL: $\underline{\text { http://jedep.spiruharet.ro }}$ \\ e-mail: office jedep@spiruharet.ro
}

Macedonian ministry can engage in direct contacts or even to conclude bilateral agreements on the consultation process concerning the project. ${ }^{28}$

Even if the competent organ of certain state was not officially informed by Republic of Macedonia for concrete project that in opinion of that country would have significant environmental impact on its territory, the Macedonian Ministry of Environment is obliged to include the competent organ of that state in the consultation procedure on its request. The public on the concerned states must obtain equal right to give comments and remarks on the project as well the domestic public in Macedonia. The Ministry of Environment when deciding on the application will take into account the remarks of the public in these countries. $^{29}$

The study on the environmental impact of the project is communicated to the competent organ of the other states. The Ministry of Environment opens consultations with an aim to reduce or eliminate the consequences of the trans-boundary pollution. The possible alternatives to the proposed project including its non - approval will be discussed, as well as other forms of mutual assistance, in order to reduce the possible harmful impact of the project. The final decision on the project should be transmitted to the competent organ of the concerned states, accompanied with the key reasons underpinning it, as well as list of the foreseen measures on the eliminating or reducing the harmful effects of the project. ${ }^{30}$

If there's project in another country that can have environmental impact in the Republic of Macedonia, and if the Ministry of Environment receives such notification, then it will respond to the notification and it is obliged to inform the Macedonian public for the project. Also, if from another source there's information about of such project in another country, the Ministry of Environment will take all necessary measure to participate in the procedure. The relevant institutions and the public will be notified for the project in order to submit their observations in certain timeframe.

The A - Ecological Permit is based on BAT. It must contain inter alia obligatory conditions regarding the emission limit values, protection measures for the air, water and soil, as well as the monitoring that will be conducted by the operator of the installation. In 2010 a Rulebook was adopted on emission limit values for substances which are obligatory in the Type A Integrated ecological permit. ${ }^{31}$

The operator is obliged to regularly update the Ministry of Environment on the results from the monitoring concerning the fulfilment the obligatory conditions contained in the permit. Also, every malfunction that could have or had significant impact on the environment should be reported as well every

\footnotetext{
${ }^{28}$ Art.93

${ }^{29}$ Art.93a

${ }^{30}$ Art.93

${ }^{31}$ Rulebook on the on emission limit values for substances which are obligatory in the A integrated ecological permit, Official Gazette, 72/2010, 27.05.2010.
} 


\author{
(online) $=$ ISSN $2285-3642$ \\ ISSN-L = 2285-3642 \\ Journal of Economic Development, Environment and People \\ Volume 2, Issue 3, 2013 \\ URL: $\underline{\text { http://jedep.spiruharet.ro }}$ \\ e-mail: office jedep@spiruharet.ro
}

change in the operation. The operator must comply with the emission limit values set in the A integrated permit, application of BAT, and is obliged to prevent or to reduce to the largest possible extent the impact of the installation to the to the environment, including the impact in the other countries. ${ }^{32}$

The Conditions of the Type A permit can be changed ex officio by the ministry, or on a request by the operator of the installation itself. The Ministry ex officio changes the conditions of the permit if newer BAT are available, the use of new technologies is essential to provide safer working conditions, because of the increased pollution of the environment that has harmful consequences for the people's health and in a event of changes in the legislation or general ecological revision prompts such changes. ${ }^{33}$

If the operator itself requests changes in the Type A permit, it must provide information regarding the changes in the operation, the extent of such changes as well as the impact that those changes will have on the environment. If the Ministry considers that the proposed changes to the operation of the plant will not result in excess of the negative pollution of the environment, it will accept the request. The procedure for amendment of the permit is the same as the procedure for granting the permit, so the participation of the public and the local authorities must be secured. ${ }^{34}$

The granted permit can be withdrawn by the Ministry if the operator has continuously more than three times infringed the conditions of the permit had made changes in the operation of the plant without the proper authorization from the Ministry of Environment or it operates outside the limits and timeframe set by the integrated permit. If the operator decides to cease the operation of the plant permanently, then it is obliged to inform the Ministry of that intention as well to propose a plan for rectification of the changes to the environment that resulted from its operation. This plan must be accepted by the Ministry of Environment. $^{35}$

All other new plants emitting harmful emissions for the people's health and environment not covered by Article 95 of Law should obtain a Type B Integrated Ecological permit. The list of these installations is adopted by the Government. These permits are issued by the mayors of the municipalities. If the installation is located in a protected area, then the permit is issued by the Ministry of Environment. The permit must list the installation and its operator and especially the requirements that the operator must fulfil in order to start operation of the plant, inter alia with regard to the monitoring of the emissions and the frequency of the measurements. The permit will be issued if the competent authority finds that the operation of the plant will not exceed the set limit values for emissions. The obtaining of the B Integrated permit is pre - condition for obtaining the permit for operation of the installations, so the competent authority will not produce operation permit without the Type B Integrated permit. The compliance with the

\footnotetext{
${ }^{32}$ Art. 107 (8), Law on the amendment of the Law on Environment, Official Gazette, 24/07

${ }^{33}$ Art.115

${ }^{34}$ Arts.116-7

${ }^{35}$ Art.120 


\author{
(online) = ISSN $2285-3642$ \\ ISSN-L = $2285-3642$ \\ Journal of Economic Development, Environment and People \\ Volume 2, Issue 3, 2013 \\ URL: $\underline{\text { http://jedep.spiruharet.ro }}$ \\ e-mail: office jedep@spiruharet.ro
}

conditions set in the permit must be checked previously by the competent local authority by performing checks on the operation of the installation. ${ }^{36}$

The Law prescribes the obligations of the operators and other natural or legal persons regarding the measures for prevention of the accidents and mitigating their impact on the environment. The operator must report to the competent organ every change to the quantities of dangerous substances, as well as the changes in the operation and technological process of the plant. Also, it is obligated to report to the competent organ any case of an accident, contingency plans that should be prepared by the operators, and the obligations of the competent state organs, including in a event of a accident with trans-boundary effects. ${ }^{37}$

According to the European Commission, Macedonia hasn't made much progress in the field of industrial pollution control and risk management. So, the 2009 Progress Report on Macedonia has noted little progress in this. The progress on the transposition of the Seveso II directive was noted, but much critic was directed of the lack of administrative capacity at local level, under training of the environmental inspectors, which resulted in delay in the issuance of the integrated ecological permits. The operators of the industrial installations have not provided contingency plans, although there's clear obligation in this regard set by the Law. ${ }^{38}$

The 2010 Report widely replicated the conclusions of the 2009 Report. The Commission noted that the Convention on the trans-boundary effects of industrial accidents was ratified and implementing legislation for control of major accident hazards involving dangerous substances and for eco-labelling was adopted. The critics were directed at the lagging with the legislation for Large Combustion Plants and the delays in the issuing of integrated permits as well as the procedures for consultation of the public. The need to strengthen the administrative capacity, particularly of the inspection services was stressed.

\title{
4. Regulation of industrial pollution in Serbia
}

The industrial pollution control in Serbia is regulated by the Law on Integrated Prevention and Control of Pollution. ${ }^{39}$ Primary industrial activities that are subject of this Law are energy, chemical industry, metal industry, cement industry, waste management facilities and other installations that have significant negative influence on environment or human health. The Law is postulated on several principles: Integrated and individual approach, Best Available Techniques, flexibility and access to information and the decision - making process for the public.

\footnotetext{
${ }^{36}$ Art.127

${ }^{37}$ Arts. 145- 156, Law on the Environment, cit.supra.

38 Macedonia 2009 Progress Report, SEC(2009) 1335, http://ec.europa.eu/enlargement/pdf/key documents/2009/hr rapport 2009 en.pdf.

${ }^{39}$ Official Bulletin of Republic of Serbia, No.135/2004.
} 


\author{
(online) = ISSN $2285-3642$ \\ ISSN-L = 2285-3642 \\ Journal of Economic Development, Environment and People \\ Volume 2, Issue 3, 2013 \\ URL: $\underline{\text { http://jedep.spiruharet.ro }}$ \\ e-mail: office jedep@spiruharet.ro
}

The integrated permit is granted by the competent authority to the industrial installation only after it has established the overall influence of that installation on the air, soil and water through its emissions, the consumption of raw materials, energy efficiency, the prevention of accidents and sanitation of the site in a event of a closure. ${ }^{40}$

The competent organ is obliged to inform the wider public as well organs and organizations in the field of agriculture, forestry, physical planning, energy sector, mining industry, and the local self-government on whose territory the installation will operate, for the request for obtaining integrated permit. These subjects can give their opinions to the competent organ for issuing the permit in a time - limit of 15 days from the receipt of the documentation. These opinions are taken into account during the preparing of the Draft permit, and again at the request of these organizations and members of the public, the Draft -permit is subject to new cycle of considerations and opinions, which are then submitted to the Technical Commission, which will assess the conditions in the Draft permit. ${ }^{41}$

The issuance of the permit requires complying with concrete conditions as well as respect of the Best Available Techniques. The competent organ enjoys certain degree of flexibility regarding the conditions of the permit, allowing in some cases less strict criteria for emissions.

The permit contains specifically conditions regarding Best available techniques, the emission limit values for the facility, measures for the protection of the air, water, soil, waste from the facility, reducing the vibrations and noise, prevention of accidents, methodology for measuring the emission limit values, the frequency of reports to be submitted, measures for start of the operation, cessation of operation in case of an accident, restoration of the environment after permanent cessation of activities of the plant etc. ${ }^{42}$ Like the relevant Macedonian Law, this Law provides a framework for consultations with another state, whose environment will suffer significant impact from the operation of a plant on the territory of the Republic of Serbia. In these cases, or when the competent authority of those concerned states make a formal request to such end, the Ministry of Environment communicates to this organ all relevant information regarding the project and provides a possibility for remarks and suggestions by the public in the State (s) concerned. The Framework for these consultations is arranged between the two states with bilateral agreements based on reciprocity and equal treatment. The competent authority of Republic of Serbia is obliged to inform the domestic public of the remarks and suggestions from the public of the concerned state, as well as to communicate to the concerned state the decision to grant or not to grant the permit and the reasons for such decision. ${ }^{43}$

\footnotetext{
${ }^{40}$ Cf. Dušan Damjanović, Nikola Mikašinović (urednici), Izazovi evropskih integracija u oblastima zaštite životne sredine i održivog razvoja lokalnih zajednica, [The Challenges of European Integration in the areas of Environmental Protection and Sustainable Development], Palgo, Beograd, 2010, p.52.

${ }^{41}$ Art.11-13 of th e Law on integrated prevention and Pollution Control cit. supra.

${ }^{42}$ Art.16

${ }^{43}$ Art. 24
} 


\author{
(online) $=$ ISSN $2285-3642$ \\ ISSN-L = 2285-3642 \\ Journal of Economic Development, Environment and People \\ Volume 2, Issue 3, 2013 \\ URL: $\underline{\text { http://jedep.spiruharet.ro }}$ \\ e-mail: office jedep@spiruharet.ro
}

The operator of the plant must fully comply with the conditions set in the permit, to report to the competent organ all changes in the operation and accidents that may have significant impact on the environment, submit an annual report on the activities of the plant, every change of the operator of the plant and to execute all measures prescribed by the competent organ after the cessation of activities. The Law provides for public access to the information regarding the issuance of the permit, participation in the decision - making process as well as access to justice/ judicial control of the process of issuance of integrated permits. In a event, that the BAT criteria cannot be satisfied in the moment of issuance of the permit, the competent organ will issue a permit containing additional requirements with a goal of complying with those standards. The existing industrial installations have a obligation to obtain an integrated permit until 2015 at the latest.

The competence for issuance of integrated permit is shared between central, county and local organs. The competent organ must ensure that all industrial installations under its territorial jurisdiction have an integrated permit, to follow the development of new technologies, to ensure monitoring of the facility, to revise of the integrated permit and updating of the conditions, to ensure information for the public regarding the conditions of the permit, the draft version of the permit, the register of issued integrated permit and the results of the revisions and monitoring of the facility.

The permit is subject to revision at least two times during its period of validity. The revision is always carried out by the competent organ if there is a need to establish new limit values for emissions, or a pollution has occurred that requires a revision of the set values in the permit, if the pollution can cause harm to the environment or to people's health, there has been substantial changes in the BAT than can provide significantly less emission values, in a event of a change in the environmental legislation or that is required for the purpose of safety of operation of the plant.

Similar with the Macedonian Law, this Law provides a possibility to terminate the permit inter alia if the permit expires, the operator stops to comply with the conditions of the permit, if the competent organ has found out that the permit is based on false or falsified documentation by the operator, the operator does not conform with the monitoring and reporting obligations, or it has not conformed with the orders of the inspector or a bankruptcy proceedings were opened.

The Law also regulates the administrative supervision which is carried by the Ministry of Environment, the work of the environmental inspectors and prescribes financial penalties for the misdemeanours or economic misdemeanours.

In 2005 the Government also prescribed the programs of measures for adjustment of the existing installations to the positive normative acts. These programs should contain the description and timetable 


\author{
(online) = ISSN $2285-3642$ \\ ISSN-L = $2285-3642$ \\ Journal of Economic Development, Environment and People \\ Volume 2, Issue 3, 2013 \\ URL: $\underline{\text { http://jedep.spiruharet.ro }}$ \\ e-mail: office jedep@spiruharet.ro
}

for the proposed measures for adjustment, the expected results of the proposed measures the monitoring and financial framework for these measures. ${ }^{44}$

In 2008 the Government has also established the dynamics for submission of the requests for integrated permits of the abovementioned subjects and activities. ${ }^{45}$

Also, the types of activities that are subject to the permit on integrated conditions were determined by the Government in 2005 and those are listed in several large categories: energy sector, metal industry, mineral industry, chemical industry, waste management and other activities. ${ }^{46}$

In 2005 the criteria on the determination of BAT were adopted by the Government. ${ }^{47}$ Among other, here the technical specifications of the plant are listed, geographical position, the environmental conditions on the location, the precautionary principle and special conditions. Special emphasis must be put on application of techniques that produce minimum waste and application of less dangerous substances, reuse of the raw materials and their recycling, the scientific progress and the new, the energy efficiency of the used raw materials, follow up of the Best available technologies, prevention of accidents and the prevention and reduction of the overall impact of the harmful emissions to the environment. ${ }^{48}$

In a event that BAT do not ensure satisfactory results in the compliance with the standards of protection of the environment, additional measures will be enshrined in the permit regarding the: 1) emission limit values 2) ban on certain polluting emissions on certain geographical areas, 3) application of priority measures in certain economic sectors, 4) financial framework for application of these measures and 5) enlisting alternative measures for improvement of the quality of the environment. ${ }^{49}$

The recent reports of the European Commission have not noted significant progress in the field of Industrial pollutions control and risk management in Serbia. The 2009 Progress Report noted the adoption of by-laws and the intention to start issuing integrated permits in 2009 and $2010 .^{50}$ The 2010 Progress

\footnotetext{
${ }^{44}$ Regulation on the contents of the program of measures for adjustment of the existing installations to the prescribed conditions, Official Bulletin of the Republic of Serbia, 84/2005.

${ }^{45}$ Regulation on the establishing the dynamics of submission of the requests for issuing of the integrated permit, Official Bulletin of the Republic of Serbia, 108/2008.

${ }^{46}$ Regulation on the types of activities and facilities subject to integrated permit, Official Bulletin of the Republic of Serbia, 84/2005

47 Regulation on the criteria for determination of the Best Available Techniques, for application of the quality standards, and determination of the emission limit values in the integrated permit, Official Bulletin of the Republic of Serbia, 84/2005.

${ }^{48}$ Art.2

${ }^{49}$ Art.3

${ }^{50}$ Serbia 2010 Progress Report, SEC(2009) 1339, http://www.europa.s/upload/document s/key documents/2009/sr rapport 2009 en.pdf., p.44
} 


\author{
(online) = ISSN $2285-3642$ \\ ISSN-L = $2285-3642$ \\ Journal of Economic Development, Environment and People \\ Volume 2, Issue 3, 2013 \\ URL: $\underline{\text { http://jedep.spiruharet.ro }}$ \\ e-mail: office jedep@spiruharet.ro
}

Report noted that the list of installations pending integrated permit is being revised, as well the start of the application of the International Plant Protection Convention. ${ }^{51}$

\title{
5. Industrial pollution regulation in Croatia
}

The Croatia is the only one of the three countries that concluded the accession negotiations in 2011, including the Chapter on Environment. It has the highest degree of approximation of its legislation in this field with the EU legislation. The Chapter on Environment was opened in February 2010, and provisionally closed in December 2010. ${ }^{52}$

Unlike Serbia, Croatia has not adopted a special Law on Industrial Pollution Control. So, the issue of the pollution from industrial installations like in Macedonia is regulated by the general Law on the Protection of the Environment.

The protection of environment from industrial installations is ensured under special heading of the Law "Integrated conditions for environmental protection. ${ }^{153}$ All installations on territory of Croatia that will emit harmful emissions into the air, soil or water before their construction or before the start of operation or reconstruction must obtain integrated conditions. These conditions should ensure prevention, reduction and in greatest possible extent elimination of the pollution at the source level. Also, the purpose is to ensure reasonable exploitation of the natural resources and establishing a balance between the economic developments with the regeneration capacities of the nature itself. ${ }^{54}$

These integrated conditions are set by the Ministry of Environment of Republic of Croatia, and are part of the location permit for the installations. These conditions must lie on best available technologies and contain conditions regarding the protection of air, water, soil and the sea. The compliance with these conditions is checked in the process of technical inspection of the plant during the process of issuing the permit to start operation. ${ }^{55}$ The process of the participation of the public in the decision-making process on the permits is regulated by secondary legislation. ${ }^{56}$

The operator of the plant is obliged inter alia to undertake all necessary measures prescribed by the relevant legislation, especially the BAT, not to produce waste, or the waste to be incinerated, or if that is

\footnotetext{
${ }^{51}$ Serbia 2010 Progress Report, SEC(2010) 1330,

http://www.europa.rs/upload/documents/key documents/2010/Rapport\%20SR\%20TO\%20PRESS\%20CONF\%2008.11 .pdf p.43

52 www.entereurope.hr

${ }^{53}$ The whole procedure was concretely defined in 2008 by the Government. See: Regulation on the procedure for establishing integrated conditions for protection of the environment, Narodne Novine, 114/08.

${ }^{54}$ Art.82

${ }^{55}$ Art.84

${ }^{56}$ Regulation on the informing and participating of the public on the environmental issues, Narodne Novine, 64/2008.
} 


\author{
(online) $=$ ISSN $2285-3642$ \\ ISSN-L = 2285-3642 \\ Journal of Economic Development, Environment and People \\ Volume 2, Issue 3, 2013 \\ URL: $\underline{\text { http://jedep.spiruharet.ro }}$ \\ e-mail: office jedep@spiruharet.ro
}

not possible, than to be disposed in a way not to cause significant harmful effects to the nature, and to ensure efficient use of the energy. ${ }^{57}$

The decision on the integrated conditions must set all conditions that the plant must satisfy, as well prescribing the modalities on inspecting the compliance with these conditions during the test period. In the areas where stricter emission limit values are set by special legislation, the decision should enlist those stricter conditions. The permit for operation of the plant confirms that the plant fulfils the conditions set in the decision on the integrated conditions. In the framework of the procedure for obtaining operation permit, during the test period an expert from the Ministry checks whether the plant fulfils the integrated conditions according to the Decision by the Ministry. ${ }^{58}$

The integrated conditions expiry for a period of five years after the permit for operation was granted. The permit for operation ceases to be valid in that part. The plant may ask for prolongation of these integrated conditions only if according to the positive legislation at the time of submission of the request, the same integrated conditions can be granted. ${ }^{59}$

The plant can start full operation only if during the test period all conditions set by the decision on integrated conditions are complied with. ${ }^{60}$ The operator of the plant after the start of the technological process must inform the Agency of Environment of the results on the monitoring of emissions in the air, soil and water, as well as to report to the inspection services any unforeseen event having significant effects on the environment. Also, every intention to change the way of operation or reconstruction must be reported to the Ministry. The Ministry ex officio is obliged to reconsider and update the integrated conditions every 5 years. These updates are necessary especially in case where new limit values of emissions should be set because of the significant pollution of the environment; if there has been significant improvement in the BAT that can significantly improve the protection of the environment, there should be new techniques introduced in order to ensure worker's safety or if that is necessary in order to achieve approximation with the Law (on Environment), or with European or International Law. ${ }^{61}$

The Law provides conditions for early termination of the decision on integrated conditions when the plant exercises significant change in the organization or has made reconstruction without the permission of the Ministry, or where the plant in a prescribed period set by the environmental inspectors does not undertake the relevant measures in order to comply with the decision on integrated conditions or the permit for operation of the plant. This also applies in a case when such measures were ordered in

\footnotetext{
${ }^{57}$ Art.83

${ }^{58}$ Art.89 (3)

${ }^{59}$ Art.90

${ }^{60}$ Art.91

${ }^{61}$ Art.94
} 


\author{
(online) = ISSN $2285-3642$ \\ ISSN-L = 2285-3642 \\ Journal of Economic Development, Environment and People \\ Volume 2, Issue 3, 2013 \\ URL: $\underline{\text { http://jedep.spiruharet.ro }}$ \\ e-mail: office jedep@spiruharet.ro
}

accordance with some special law, and the plant does not comply with the decision of the inspection services. ${ }^{62}$

The Law sets obligation for all operators of plants dealing with dangerous substances to undertake all measures in order to prevent, to eliminate or to reduce the risk of potential accidents, and also to reduce their potential effects to people, property and the environment. These measures as well as concrete proof of the taken measures are to be communicated to the Ministry of Environment. The Ministry should be notified by the operator for every construction of a facility, or a reconstruction before the obtainment of the decision on integrated conditions, on the increase of the quantity or the nature of physical form of the dangerous substances as well as the subsequent changes in the procedure for dealing with such substances, that can increase the risk of accidents and in a case of permanent cessation of activities of the plant. $^{63}$

In a case of an accident, the operator must promptly alert the Ministry of Environment and the central body competent for protection and rescues concerning the accidents, the released dangerous substances during and after the accident. Also, the operator shall make an assessment of the consequences for the people's health and environment and the undertaken additional measures, measures for reducing the medium and long-term consequences from the accident and measures eliminating the probabilities that such accident will happen in the future. ${ }^{64}$ If contrary to the Safety Brief, the plant introduces changes in the technological process, changes the way of operation, the type and quantities of dangerous substances that can cause major accidents, or if it permanently ceases to operate, then the operator must exercise revision and, if necessary, to update the Safety Brief and inform the Ministry as well as the organ competent for protection and rescue for these steps. ${ }^{65}$ The measures for prevention and procedure of acting of operators and competent organs in a case of an accident were in detail regulated in 2008 by secondary legislation. ${ }^{66}$

The Register of all plants operating with dangerous substances is run by the Agency of Environment, as well as all reported accidents on these plants. On the basis of this Register the Ministry of Environment organizes an exchange of information with the central body for protection and rescue, with a purpose of enabling the plants dealing with dangerous substances on the ratio between the undertaken safety measures and the nature and overall risk of occurrence of a major accident. ${ }^{67}$

In the recent years, Croatia has obtained relatively high marks by the European Commission on the issue of industrial pollution prevention and control. The 2009 Progress Report on Croatia noted significant

\footnotetext{
${ }^{62}$ Art.95

${ }^{63}$ Art.98

${ }^{64}$ Art.105

${ }^{65}$ Art.103

${ }^{66}$ Regulation on prevention of major accidents involving dangerous substances, Narodne Novine 114/08.

${ }^{67}$ Arts.186 and 106.
} 


\author{
(online) = ISSN $2285-3642$ \\ ISSN-L = $2285-3642$ \\ Journal of Economic Development, Environment and People \\ Volume 2, Issue 3, 2013 \\ URL: $\underline{\text { http://jedep.spiruharet.ro }}$ \\ e-mail: office jedep@spiruharet.ro
}

improvements in this field, notably the Implementing legislation under IPPC and SEVESO II Directive, as well as the establishment of registers of installations falling under these directives. ${ }^{68}$

In the latest 2010 Progress Report, Commission considered that Croatia has achieved good progress in the area of industrial pollution and risk management. The establishment of European Pollutant Release and Transfer Register (EPRTR) has advanced well, as well as the alignments of the existing installation with the requirements under the IPPC Directive and Large Combustion Plants Directive is stepped up. Still, Commission notes the administrative capacity for the implementation of legislation needs to be further strengthened. ${ }^{69}$

\title{
6. Conclusion
}

The awareness of the problem of the impact of the emissions released by industrial installations in the air, water and soil, in the European Union in the recent period led to the adoption of new streamlined legislation regarding the industrial emissions embodied in the new Directive 2010/75/EU. This Directive inter alia sets new, stricter emission targets for certain polluting substances (especially NOx) and timetable for their compliance by the Member States and industrial operators on their territory. The aim was to offer high level of protection of the environment and human health, while simplifying the legislation and cutting the unnecessary administrative costs. The Directive came into force on 6 January 2011, and the Member States should take necessary steps for transposition by 6 January 2013.

Macedonia, Serbia and Croatia under the Stabilization and Association Agreements have obligations in the field of industrial pollution control and risk management. This important aspect of the Environmental Policy was monitored by the Commission in its annual reports. So far, only Serbia has adopted a special Law on Integrated Prevention and Control of Pollution, while in Macedonia and Croatia the provisions regarding the industrial emissions control are enshrined in the general Law on the Environment, as well as the secondary legislation adopted in that regard. Most advanced of the three countries in this field is Croatia, followed by Macedonia and then Serbia. However, the analysis and the comparison of the legislation regarding industrial pollution control in the three countries reveals certain disparities with the corresponding European legislation. After the adoption of the new Directive on industrial emissions in 2010, Macedonia and Croatia should adopt special Laws on integrated pollution and control having in mind the importance and the complexity of the European legislation in this field. Serbia should also align its existing Law on integrated pollution with the new Directive, since the existing version and the subsequently adopted secondary legislation only scarcely regulates this complex area. Substantial amendments in all three countries should be made on the more adequate, effective and as early as possible participation of

\footnotetext{
${ }^{68}$ Croatia 2009 Progress Report, $\{\operatorname{COM}(2009)$ 533, http://ec.europa.eu/enlargement/pdf/key documents/2009/hr rapport 2009 en.pdf, p.62.

${ }^{69}$ Croatia 2010 Progress Report, SEC(2010) 1326, http://www.mvpei.hr/custompages/static/hrv/files/101110 Izvijesce o napretku HR za 2010.pdf, p.59-60. 


\author{
(online) = ISSN $2285-3642$ \\ ISSN-L = 2285 - 3642 \\ Journal of Economic Development, Environment and People \\ Volume 2, Issue 3, 2013 \\ URL: $\underline{\text { http://jedep.spiruharet.ro }}$ \\ e-mail: office jedep@spiruharet.ro
}

the public in the decision-making process concerning the issuing of the integrated permits, appropriate access of the public to judicial overview of the decisions, better cooperation with the non-governmental organizations active in the field of environmental protection, aligning the emission target values in accordance with the new Directive, streamlined provisions on carrying out the inspections and enactment of inspection plans and shorter periods for revision of the issued permits, opt-out provisions for the existing installations, transitional national plans etc. Although the timeline for the Member States of EU to transpose the Directive is until 2013, especially Macedonia and Serbia should take necessary steps for preparation of this alignment of their legislation as well its adoption in that time-limit. Also, further strengthening of the administrative capacity and the expertise of the environmental inspectors in Macedonia and Serbia especially at local level is needed to ensure effective implementation of the legislation and ensure compliance and necessary revisions of the issued permits. This is especially important for these two countries, because it can eliminate the unnecessary prolongation of the future accession negotiations in the Chapter 27 on Environment, having in mind that this is one of the most complex chapters in the negotiations.

\title{
7. References
}

[1] Tiwary, A., Colls, J., Air Pollution: Measurement, modelling and mitigation, Abingdon, Routledge, 2010.

[2] Damjanović, D., Mikašinović,N., (urednici), Izazovi evropskih integracija u oblastima zaštite životne sredine $i$ održivog razvoja lokalnih zajednica, [The Challenges of European Integration in the areas of Environmental Protection and Sustainable Development], Palgo, Beograd, 2010.

[3] Directive 2010/50/EU, Official Journal of EU, L 334/50, 17.12.2010

[4] Law on the Environment, Official Gazette of the Republic of Macedonia, 53/05, 05.07.2005.

[5] Law on the amendment of the Law on Environment, Official Gazette of Republic of Macedonia, 24/07, 01.03.2007.

[6] Regulation on the determination of the activities of the installations subject to integrated ecological permit or a permit for harmonization with a operational plan and timetable for submitting applications for permits for harmonization with a operational plan, Official Gazette of Republic of Macedonia, 89/05, 21.10.2005.

[7] Rulebook on the on emission limit values for substances which are obligatory in the A integrated ecological permit, Official Gazette, 72/2010, 27.05.2010.

[8] Law on Integrated Prevention and Control of Pollution, Official Bulletin of Republic of Serbia, No.135/2004.

[9] Regulation on the contents of the program of measures for adjustment of the existing installations to the prescribed conditions, Official Bulletin of the Republic of Serbia, 84/2005.

[10] Regulation on the establishing the dynamics of submission of the requests for issuing of the integrated permit, Official Bulletin of the Republic of Serbia, 108/2008.

[11] Regulation on the types of activites and facilites subject to integrated permit, Official Bulletin of the Republic of Serbia, 84/2005.

[12] Regulation on the criteria for determination of the Best Available Techniques, for application of the quality standards, and determination of the emission limit values in the integrated permit, Official Bulletin of the Republic of Serbia, 84/2005.

[13] Regulation on the informing and participating of the public on the environmental issues, Narodne Novine, $64 / 2008$.

[14] Regulation on the procedure for establishing integrated conditions for protection of the environment, Narodne Novine, 114/08 


\author{
(online) $=$ ISSN $2285-3642$ \\ ISSN-L = 2285 - 3642 \\ Journal of Economic Development, Environment and People \\ Volume 2, Issue 3, 2013 \\ URL: http://jedep.spiruharet.ro \\ e-mail: office jedep@spiruharet.ro
}

[15] Regulation on prevention of major accidents involving dangerous substances, Narodne Novine 114/08.

[16] European

Commission,

COM

(2005)

446 , http://europa.eu/legislation_summaries/environment/air_pollution/I28159 en.htm

[17] European Commission, Serbia 2010 Progress Report, SEC(2010) 133, 9 November 2010, http://www.europa.rs/upload/documents/key documents/2010/Rapport\%20SR\%20TO\%20PRESS\%20CONF\%200 8.11.pdf.

[18] European

$$
\text { Commission, Croatia } 2009 \text { Progress Report, SEC(2009)1333/2, }
$$
http://www.delhrv.ec.europa.eu/files/file/progres\%20report/CROATIA\%202009\%20PROGRESS\%20REPORT.pdf

[19] European Commission, Croatia Progress Report 2010, SEC(2010) 1326, http://www.delhrv.ec.europa.eu/files/file/ progres \%20report/ hr rapport 2010 en.pdf,

[20] European Commission, Macedonia 2009 Progress Report, SEC(2009) 1335 http://ec.europa.eu/enlargement/pdf/key documents/2009/mk rapport 2009 en. pdf.

[21] European Commissin, Macedonia 2010 Progress Report, SEC(2010)1332, 9 November, 2010, http://www.delmkd.ec.europa.eu/en/bilateral-relations/pdf/mk_rapport 2010 en.pdf. 